\title{
Destabilizing factors of urban renovation
}

\author{
Dmitriy Topchiy ${ }^{1,{ }^{*}}$, Ekaterina Kochurina ${ }^{1}$, and Sergey Ekba ${ }^{1}$ \\ ${ }^{1}$ Moscow State University of Civil Engineering, 26, Yaroslavskoye Shosse, 129337, Moscow, Russia
}

\begin{abstract}
To optimize the organizational and technological model of construction of buildings and structures in a dense urban environment, it is necessary to take into account the factors that have a destabilizing effect on the process of construction and installation works, and arising from the very definition of " constrained urban development", which involves getting near buildings, structures and linearly extended objects in the zone of influence of new construction or reconstruction. This article highlights a number of destabilizing factors that most strongly affect the time and economic costs that must be considered when developing a construction project.
\end{abstract}

\section{Introduction}

At present, there is no specialized normative and technical framework for regulation of construction operations in confined areas. The need for construction in confined areas is due to the continuous population growth throughout the world. Unlike Russia, which still has some reserves of unpopulated territories to be developed for residential purposes in accordance with the Regulations on the Procedure for Land Use Demarcation, in foreign countries such lands are much more limited with a resulting need for new construction on plots that have been used previously, including those in the proximity to existing buildings and structures.

The higher the plot use ratio, the more probable it is that the choice of construction organization methods on the construction site will be affected by factors that characterize the conditions of construction operations as confined [1,2].

Consideration of the term of "high-density urban development" and its definition as development of residential/urbanized territories, where adjacent buildings, structures and continuous facilities are affected by new construction or reconstruction projects, require determination of a number of destabilizing factors that hinder construction and installation works.

\section{Materials and Methods}

According to preliminary analysis, the following destabilizing factors caused by confined conditions can be identified:

\footnotetext{
* Corresponding author: aljurgaitis@gmail.com
} 
- Obstacles created by limited space on the construction site and adjacent territories, including the existing buildings and structures;

- Width, height, length and depth limitations attributable to space limitations on the construction site and leading to restrictions in the location of construction machinery, driveways for large size vehicles, construction camps, warehouses, etc.;

- The need to relocate a section of a developed municipal facility network from the construction footprint;

- Special parameters of selecting construction machinery to perform works in the said conditions;

- Various impacts on the environmental situation, including increased risks for the construction site staff and the residents of the adjacent neighborhood [3].

According to binding Annex B "Regulatory indicators of built-up density in territorial zones" Code 42.13330.2016 "Urban construction. Planning and Development of Municipal and Rural Settlements. Revised edition of Construction Norms and Regulations SNiP 2.07.01-89*", urban built-up density can be measured by:

- Ratio of built-up area to total area - calculated as the ratio of the area occupied by buildings and structures to the total area of the plot, in other words - the quarter;

- Ratio of built-up density - calculated as the ratio of the area of all floors of the project to the total area of the plot, in other words - the quarter.

An integrated indicator of the degree of impact of external environment factors on the complexity of construction and installation works in restrained urban conditions Pex(Potential External Factors) is supposed to be used only when multi-storey residential buildings are constructed on territories with a ratio of built-up area to total area equal to 0.4 or higher [4].

The ratio of built-up area to total area is calculated according to the following formula (1):

$$
\mathrm{Ks}=\mathrm{Ps} / \mathrm{Pu}
$$

Where Ps is the area of the construction project taking into account the external boundaries of the building being constructed, $\mathrm{m}^{2}$;

$\mathrm{Pu}$ is the built-up area, $\mathrm{m}^{2}$.

For the purpose of identification of destabilizing factors affecting construction and installation works in restrained urban conditions analysis has been made for the effective norms and specifications that regulate options for such construction operations in the Russian Federation.

The main regulation for construction and installation works in Russia is Code 48.13330.2011 "Organization of Construction. Revised edition of Construction Norms and Regulations SNiP 12-01-2004 (as modified by Amendment 1)".

This document regulates works of construction of new projects, reconstruction and repurposing of existing projects (buildings, structures) and also applies to organization of major repair works for existing capital construction projects.

This code determines the functions of participants in the construction process, lays down the requirements to the development of organizational and technological documentation and also specifies the sequence and rules of organization of construction works. This document fails to take into account particular features of organization of construction works on urbanized territories, but is used as a fundamental guidance for organization of construction operations $[5,6]$.

The construction projects affected by the constraint factors in the calculation model have been identified and assessed by myself and the supervisor of my graduation qualification thesis assisted by a group of 180 experts. This group included project 
managers, engineers and designers involved in construction operations on urbanized territories and facing ongoing challenges associated with the urban built-up density.

These projects were the most frequent targets of constraint factors of construction on urbanized territories and required particular attention from developers of construction organization projects and work production plans of urbanized territories.

The identified factors are listed in Table 1.

Table 1. Constraint factors.

\begin{tabular}{|c|l|}
\hline No. & \multicolumn{1}{|c|}{$\begin{array}{c}\text { Construction and installation projects affected by adverse factors } \\
\text { associated with construction and installation works on urbanized territories }\end{array}$} \\
\hline 1. & Existing utility networks \\
\hline 2. & Metro (metro tunnels) \\
\hline 3. & $\begin{array}{l}\text { Existing underground structures (for example, sewage collectors, old foundations on } \\
\text { the construction site) }\end{array}$ \\
\hline 4. & $\begin{array}{l}\text { Transport networks (possibility of delivery of large size machinery to the } \\
\text { construction site) }\end{array}$ \\
\hline 5. & Traffic intensity \\
\hline 6. & Location of construction camps \\
\hline 7. & Location of stock areas \\
\hline 8. & Location of materials handling zones \\
\hline 9. & Large mechanical aids \\
\hline 10. & $\begin{array}{l}\text { Existing buildings and structures in close proximity to the construction site } \\
\text { boundaries }\end{array}$ \\
\hline 11. & Environmental situation in the adjacent built-up area \\
\hline 12. & Location of pedestrian areas \\
\hline 13. & Location of workshops \\
\hline
\end{tabular}

\section{Results and discussion}

According to the interviewed experts, each of the above-mentioned factors exerts the greatest influence on construction and installations works and requires considerable resources and time for minimizing its influence depending on the existing infrastructure in the area of new construction or reconstruction $[6,7,8]$.

The identified factors were subsequently analyzed with reference to a regulatory technical framework that would determine variability of solutions for elimination/minimization of the impact of these factors on construction and installation operations.

a) Availability of existing utility networks.

Utility networks are understood as a complex of facilities owned by a legal or governmental entity and operated for the purpose of supplying heat, hot and cold water, communications, special communications, and electric power.

The following regulatory and technical documentation has been developed with regard to this object of research:

a) a capital construction project can be connected to the existing facilities without constructing new utility networks or reconstructing the existing ones [9].

This approach is governed by Ruling of the Government of the Russian Federation No. 83 "On Approval of the Rules of Determination and Provision of Technical Specifications for Connection of Capital Construction Projects to Utility Networks" and the "Rules of Connection of Capital Construction Projects to Utility Networks" dated February 13, 2006.

The possibility of connection to the existing engineering networks depends on the maximum load allowed by the technical specifications for the network to be connected. 
Technical specifications for the maximum load are developed by executive authorities of the subjects of the Russian Federation on the basis of the following information [10]:

- Availability of permission for the use of a particular land plot;

- Degree of development of the land plot with account for the new construction area, for which technical specifications are being developed;

- Account for requirements of the region, where the new construction is planned;

- Information reflecting the existing network layout on the proposed construction site;

- Analysis of existing land plots in terms of their dimensions.

b) Availability of a metro (metro tunnels).

Permission for construction/repurposing of buildings in technical and protected metro zones as well as preparations therefor are governed by the provisions of Governmental Ruling No. 50 "On the Procedure of Preparation and Obtaining Permissions for Construction and Reconstruction of Town Planning Objects in the City of Moscow" dated 07.09.2003.

According to Order No. 52 of the Moscow Architectural Committee on the "Rules of the Use of the Territories of Technical and Protected Metro Zones in the City of Moscow" dated 03.13.2006, construction or reconstruction/repurposing of buildings or structures, or construction of linear communication facilities in the zones identified as the territory of technical or protected zones of influence of shallow metro lines and surface metro facilities are not allowed. No permission can be obtained for construction in such areas. These requirements are aimed at protection of these facilities from external impacts.

At the same time, if construction or reconstruction of projects, or landscaping is planned farther than 30 meters from the technical zones of influence of metro facilities, it requires an expert conclusion of authorized organizations in charge of these territories, and construction must be implemented in accordance with an Approved Land Plot Use Statement.

c) Existing underground structures (for example, sewage collectors, old foundations on the construction site) $[11,12]$.

This type of works is regulated by Construction Rule 325.13258800.2017 "Buildings and Structures. Rules for Dismantling and Recycling Works".

This document governs the works of dismantling or demolition as well as partial or complete recycling of structures and applies both to industrial and civil projects.

On the basis of inspection results a fundamental document is drawn up for demolition of buildings or sections of structures or dismantling of these structures.

d) Transport networks (possibility of delivery of large size machinery to the construction site).

A great number of factors of influence should be taken into consideration in the planning of delivery of construction machinery to a new construction site.

According to Order of the Labor Ministry of Russia No. 336n "On Approval of the Labor Safety in Construction" dated 06.01.2015, organization of transportation of largesized construction machinery for such projects must take into account:

1) Dimensions of the construction machinery being transported;

2) Bridges on the construction machinery transportation route;

3) Tunnels on the construction machinery transportation route;

4) Passages on the construction machinery transportation route [13, 14];

5) Rules of transportation of large-sized and heavy cargo on sectors of public roads. These rules are established by Order of the Ministry of Construction of Russia No. 258 dated 07.24.2012. Such permission is usually obtained by the contractor in charge of transportation.

Construction machinery is selected at the design stage with account for the following factors: 
1) The type of construction machinery, which is required and sufficient for the applied work technologies, and whether it is appropriate for the work conditions;

2) Designation of operation zones of the selected machinery associated with potential risks for workers and persons not involved in the construction process;

3) Determination of conditions of operations of construction machinery taking into account the wedge of failure of the earth foundation [15].

Due to lack of any regulations for these works, the delivery mode and in fact the possibility of using large-size machinery on the construction size subject to the possibility/impossibility of its delivery to the point of destination depends to a large extent on the ability of the officer in charge of this job to organize delivery of machinery to the work area.

e) Traffic intensity [16]

Clause 6.2.5.1 of Construction Rule No. 48 dated 08.26.2016 requires optimization of the construction materials delivery schemes to minimize transshipment costs.

A work performance project must include a technological chart of consumption and delivery of construction materials to the construction site.

These diagrams reflect the need for construction materials with reference to the commencement and completion dates of the works requiring particular materials (in order to identify the daily need for construction materials, analysis must be made with regard to the number of work crews, their composition, number of shifts and the degree of efficiency of operations of these crews).

Delivery of construction materials depends on the consumption rate of construction materials. Thus, if the work schedule (approved calendar plan) is strictly determined with a stable rate of consumption, delivery can be organized at varying rates and intervals, but ensuring sufficiency of materials in accord with consumption.

f) Construction camps [17]

According to clause 6.2.5.1 of Construction Rule No. 48 dated 08.26.2016, temporary construction infrastructure facilities, in this case construction camps, must be located on the construction site with account for the following requirements:

1) Costs of temporary facilities must be minimized through maximum use of existing facilities such as roads, utility networks and buildings/structures located on the construction site;

2) Ensuring appropriate and sufficient accommodation facilities for the workers employed on the construction site through the use of mobile buildings and structures.

Clause 6.2.6 of Construction Rule No. 48 dated 08.26.2016 allows allocation of temporary facilities required for construction needs on territories lying off the construction site under a contract with the territory's owner.

g) Production workshops

The need for allocation of production workshops is also regulated by clause 6.2.5.1 of Construction Rule No. 48 dated 08.26.08.2016.

These facilities are a part of the temporary construction infrastructure.

Requirements to allocation of production workshops on the construction site are similar to those for construction camps.

The technological sequence of construction and installation works and the completion schedules for these works directly depend on the workshop location.

h) Stock areas

Similarly to construction camps and production workshops.

Stock areas should be located as close as possible to the sector, where the stored items will be used.

In addition to the requirements of clauses 6 and 7, cargo handling zones should include sufficient working space $[18,19]$. 
Thus, according to Construction Rule No. 48.13330.2010, cargoes may not be carried horizontally for over 50 meters, while the use of manual cargo carrying aids on staircases and stepladders is prohibited.

The distance between the cargo and the cargo-handling equipment may not be less than 1 meter.

If existing structures are used for stock facilities, and the latter are located above the ground floor of the building being constructed with more than one flight of stairs being arranged or with the height exceeding 2 meters, approaches to such stock areas must be equipped with cargo lifting mechanisms.

i) Cargo handling zones

Allocation of cargo handling zones on the construction site is also regulated by the provisions of Construction Rule No. 48.

According to the provisions of Ruling of the State Construction Committee of Russia No. 80 dated 07.23.2001 and Construction Rule No. 49.13330.2010 dated 07.23.2001, cargo handling works on construction sites are subject to conformity to a number of requirements set forth in the above-mentioned documents and focused on ensuring safety of cargo handling operations.

A number of factors that determine location of cargo handling zones can be identified:

1) Planned cargo flow, which in its turn depends on the construction materials consumption rate;

2) Type of cargo to be handled at each point;

3) Type of cargo handling means;

4) Number of parties involved in cargo handling works.

Technical regulations include a number of requirements to the sites used for cargo handling operations:

j) Large mechanical aids

Construction machinery is selected at the construction project design stage depending on the organizational and technological solutions, which in turn depends on [20]:

- Soil conditions on the new construction site;

- Degree of complexity and scope of works;

- Number of workers operating the construction machinery;

- Possibility of using various options of location of construction machinery in accordance with the requirements of Construction Rule No. 49.13330.2010.

Construction machinery is selected with account for the following factors [21]:

1) Possibility of the use of large-size machinery in compliance with the provisions of the documents that regulate the labor safety in construction, for example, those related to delineation of hazardous areas of operations of construction machinery. Requirements to minimal distances to the boundaries of hazardous cargo movement zones or zones with falling load risks are specified in Table D1 of Annex D to Construction Rule No. 49.13330.2010;

2) Restrictions of access of large-size machinery to the construction site determined by dimensions of the roadbed and passing options for construction machinery on the construction site;

3) Environmental requirements to construction machinery (levels of noise, vibration and exhaust gases);

4) Cost of use of construction machinery;

5) Projected construction scope;

6) Number of work shifts in various construction periods.

k) Existing buildings and structures in close proximity to the construction site boundaries 
According to Order of the Ministry of Regional Development of Russia No. 624 dated 12.30.2009, the development of design documentation for a construction project must include engineering surveys in the areas, where existing buildings and structures are affected by the construction.

Based on the findings of engineering surveys, the following information is used in the development of initial documentation:

1) Technical condition of supporting structures of the building (foundations affected by the new construction);

2) Technical characteristics of the earth foundation;

3) Existing defects and damage;

4) Actual loads on the surveyed structures.

Such information must be sufficient for responsible officers of the customer to make a conclusion on the need for developing any additional documentation on strengthening the existing structures [22].

The customer also hires an organization to monitor the existing structures on the construction site with the purpose of keeping track of any alterations that occur therein during the whole period of construction and installation works.

\section{Conclusion}

Construction sites are monitored by local authorities in terms of compliance with the requirements of normative documents that regulate environmental loads on the adjacent built-up areas.

Manufacturer specifications for construction machinery specify its environmental load class. Officers responsible for the development of initial documentation for a future construction project should select machinery that would meet the requirements of minimum aggregate load of construction machinery on the environment at any given period.

\section{References}

1. D.V. Topchy, Scientific Review 9, 114-117 (2017)

2. D.V. Topchy, Housing construction 7, 16-19 (2007)

3. D. Gura, Y. Dubenko, E. Dyshkant, A. Pavlyukova, G. Akopyan, IOP Conference Series: Earth and Environmental Science 403(1), 012184 (2019). DOI: 10.1088/1755$1315 / 403 / 1 / 012184$

4. D.A. Gura, I.G. Markovskii, B.A. Hahuk, S.K. Pshidatok, IOP Conference Series: Materials Science and Engineering 698(4), 044014 (2019). DOI: 10.1088/1757899X/698/4/044014

5. D.V. Topchy, Architecture and construction of Russia 5, 14-21 (2011)

6. D.V. Topchy, Technology and organization of construction production 1, 46-47 (2014)

7. Z. Bonić, G.T. Ćurčć, M. Trivunić, N. Davidović, N. Vatin. Procedia Engineering. 2015. 117(1). 419-430. DOI:10.1016/j.proeng.2015.08.189

8. D.V. Topchy, Technology and organization of construction production 4, 34-41 (2014)

9. D.V. Topchy, European Research 6(7), 6-9 (2015)

10. D.V. Topchiy, V.A. Skakalov, A.Yu. Yurgaytis, International Journal of Civil Engineering and Technology (IJCIET) 9(1), 985-993 (2018)

11. D. Topchiy, A. Shatrova and A. Yurgaytis, MATEC Web of Conferences 193, 05032 (2018) 
12. D. Topchiy and E. Kochurina, MATEC Web of Conferences 193, 05012 (2018)

13. D. Topchiy and A. Tokarskiy, MATEC Web of Conferences 196(1), 04029 (2018)

14. D.V. Topchiy, A.I. Shatrova, International Journal of Mechanical Engineering and Technology 4(9), 539-547 (2018)

15. D. Topchiy, A. Tokarskiy, IOP Conference Series: Materials Science and Engineering 365, 1-7 (2018)

16. I. Potekhin, V. Mischenko, A. Mottaeva, A. Zheltenkov, E3S Web of Conferences, 33, 03020 (2018) doi: 10.1051/e3sconf/20183303020

17. I.L. Abramov, A.A. Lapidus, E3S Web of Conferences 33, 03066 (2018)

18. I. Abramov, E3S Web of Conference 33, 03075 (2018)

19. A. Lapidus, I. Abramov, MATEC Web of Conferences 193, 05033 (2018)

20. A. Lapidus, I. Abramov, IOP Conf. Ser.: Material Science 365, 062002 (2018)

21. A. Mottaeva, MATEC Web of Conferences 106, 08071 (2017)

22. I. Abramov, A. Stepanov, I.F. Ibrahim, MATEC Web of Conferences 117, 00001 (2017) 